\title{
Photobacterium gaetbulicola sp. nov., a lipolytic bacterium isolated from a tidal flat sediment
}

\author{
Young-Ok Kim, ${ }^{1}$ Kyung-Kil Kim, ${ }^{1}$ Sooyeon Park, ${ }^{2}$ So-Jung Kang, ${ }^{2}$ \\ Jeong-Ho Lee, ${ }^{3}$ Sang-Jun Lee, ${ }^{1}$ Tae-Kwang $\mathrm{Oh}^{2}$ and Jung-Hoon Yoon ${ }^{2}$
}

Correspondence Jung-Hoon Yoon jhyoon@kribb.re.kr

\author{
${ }^{1}$ Biotechnology Research Division, National Fisheries Research and Development Institute (NFRDI), \\ Gijang, Busan 619-705, Republic of Korea \\ ${ }^{2}$ Korea Research Institute of Bioscience and Biotechnology (KRIBB), PO Box 115, Yusong, \\ Taejon, Republic of Korea \\ ${ }^{3}$ Genetics and Breeding Research Center, National Fisheries Research and Development Institute \\ (NFRDI), Geoje 656-842, Republic of Korea
}

\begin{abstract}
A Gram-negative, motile, non-spore-forming and lipolytic bacterial strain, designated Gung $47^{\top}$, was isolated from a tidal flat on the west coast of Korea. Strain Gung $47^{\top}$ grew optimally at $30{ }^{\circ} \mathrm{C}$ and with 2-5\% (w/v) NaCl. Phylogenetic analyses based on 16S rRNA gene sequences revealed that strain Gung $47^{\top}$ belonged to the genus Photobacterium. Strain Gung $47^{\top}$ exhibited $98.1 \%$ 16S rRNA gene sequence similarity with Photobacterium rosenbergii LMG $22223^{\top}$ and 94.3$96.3 \%$ similarity with other type strains of species of the genus Photobacterium. Strain Gung $47^{\top}$ exhibited $47 \%$ DNA-DNA relatedness to $P$. rosenbergii LMG $22223^{\top}$. Strain Gung $47^{\top}$ contained Q-8 as the predominant ubiquinone and $\mathrm{C}_{16: 1} \omega 7 \mathrm{c}$ and/or iso- $\mathrm{C}_{15: 0} 2-\mathrm{OH}, \mathrm{C}_{16: 0}$ and $\mathrm{C}_{18: 1} \omega 7 \mathrm{c}$ as the major fatty acids. In this study, two closely related type strains, $P$. rosenbergii LMG $22223^{\top}$ and Photobacterium halotolerans LMG $22194^{\top}$, were also found to have Q-8 as the predominant ubiquinone. The DNA G $+C$ content of strain Gung $47^{\top}$ was $50.6 \mathrm{~mol} \%$. The differential phenotypic properties together with the phylogenetic and genetic distinctiveness of strain Gung $47^{\top}$ demonstrated that this strain is distinguishable from recognized Photobacterium species. Therefore, strain Gung $47^{\top}$ is considered to represent a novel species of the genus Photobacterium, for which the name Photobacterium gaetbulicola sp. nov. is proposed. The type strain is Gung $47^{\top}\left(=\right.$ KCTC $22804^{\top}=$ CCUG $\left.58399^{\top}\right)$.
\end{abstract}

The genus Photobacterium was first proposed by Beijerinck (1889) and belongs phylogenetically to the class Gammaproteobacteria (Anzai et al., 2000). At the time of writing, the genus Photobacterium comprised 16 species with validly published names: Photobacterium phosphoreum (Beijerinck, 1889) (the type species), P. leiognathi (Boisvert et al., 1967), P. fischeri (Beijerinck, 1889; Reichelt \& Baumann, 1973), $P$. angustum (Reichelt et al., 1976), P. damselae (Smith et al., 1991), P. iliopiscarium (Onarheim et al., 1994; Urakawa et al., 1999), P. profundum (Nogi et al., 1998), P. indicum (Xie \& Yokota, 2004), P. rosenbergii (Thompson et al., 2005), P. lipolyticum (Yoon et al., 2005), P. frigidiphilum (Seo et al., 2005a), P. aplysiae (Seo et al., 2005b), P. ganghwense (Park et al., 2006), P. halotolerans (Rivas et al., 2006), P. lutimaris (Jung et al., 2007) and P. kishitanii (Ast et al., 2007). Members of the genus Photobacterium have been isolated from marine organisms, marine sediments,

Abbreviation: TCN, tricaprylin.

The GenBank/EMBL/DDBJ accession number for the $16 \mathrm{~S}$ rRNA gene sequence of strain Gung $47^{\top}$ is GQ260188. seawater and saline lakes (Ast et al., 2007; Seo et al., 2005a; Farmer \& Hickman-Brenner, 2006; Park et al., 2006; Rivas et al., 2006; Thompson et al., 2005). In this study, we describe a lipolytic bacterial strain, designated Gung $47^{\mathrm{T}}$, which was isolated from a tidal flat sediment on the west coast of Korea.

Strain Gung $47^{\mathrm{T}}$ was isolated by means of the standard dilution plating technique at $25{ }^{\circ} \mathrm{C}$ on marine agar 2216 (MA; Difco). The type strains of three Photobacterium species were used as reference strains for phenotypic characterization, fatty acid analysis and DNA-DNA hybridization: $P$. rosenbergii LMG $22223^{\mathrm{T}}$ and $P$. halotolerans LMG $22194^{\mathrm{T}}$ were obtained from LMG, Ghent, Belgium, and P. ganghwense KCTC $12328^{\mathrm{T}}$ was obtained from KCTC, Taejon, Korea. The morphological, physiological and biochemical characteristics of strain Gung $47^{\mathrm{T}}$ were investigated using routine cultivation on marine agar 2216 (MA; Difco) at $30{ }^{\circ} \mathrm{C}$. Cell morphology was examined by light microscopy (E600; Nikon) and transmission electron microscopy (CM-20; Philips). Flagellation was determined by transmission electron microscopy with cells 
Table 1. Differential phenotypic characteristics of strain Gung $47^{\top}$ and its closest phylogenetic neighbours

Strains: 1, Photobacterium gaetbulicola sp. nov. Gung $47^{\mathrm{T}} ; 2, \quad P$. rosenbergii LMG $22223^{\mathrm{T}}$ (unless indicated, data from Thompson et al., 2005); 3, P. lutimaris DF-42 ${ }^{\mathrm{T}}$ (Jung et al., 2007); 4, P. halotolerans LMG $22194^{\mathrm{T}}$ (Rivas et al., 2006); 5, P. ganghwense KCTC $12328^{\mathrm{T}}$ (Park et al., 2006). All strains were positive for motility, nitrate reduction, catalase (data for P. rosenbergii LMG $22223^{\mathrm{T}}$ from this study; weak for P. ganghwense KCTC $12328^{\mathrm{T}}$ ), oxidase, hydrolysis ${ }^{\star}$ of tyrosine and Tweens 20, 40, 60 and 80, utilization* of D-galactose, D-glucose, maltose, trehalose, citrate, L-malate, pyruvate and succinate, acid production $^{*}$ from D-fructose and D-ribose, activity* of alkaline phosphatase, esterase (C4) and esterase lipase (C8) and susceptibility to chloramphenicol, gentamicin, neomycin and streptomycin. All strains were negative for Gram-staining, $\mathrm{H}_{2} \mathrm{~S}$ production (data for $P$. rosenbergii LMG $22223^{\mathrm{T}}$ from this study), hydrolysis of urea*, utilization $^{*}$ of benzoate, formate and L-glutamate, acid production ${ }^{\star}$ from melezitose and D-sorbitol, activity ${ }^{\star}$ of valine arylamidase, trypsin, $\alpha$-chymotrypsin, $\alpha$ - and $\beta$-galactosidase, $\beta$-glucuronidase, $\alpha$ - and $\beta$ glucosidase, $\alpha$-mannosidase and $\alpha$-fucosidase and susceptibility ${ }^{\star}$ to oleandomycin. + , Positive; $\mathrm{w}$, weakly positive; - , negative.

\begin{tabular}{|c|c|c|c|c|c|}
\hline Characteristic & 1 & 2 & 3 & 4 & 5 \\
\hline \multicolumn{6}{|l|}{ Growth at: } \\
\hline $4{ }^{\circ} \mathrm{C}$ & - & - & + & + & - \\
\hline $40{ }^{\circ} \mathrm{C}$ & + & - & + & - & + \\
\hline \multicolumn{6}{|l|}{ Hydrolysis of:* } \\
\hline Aesculin & + & + & + & - & - \\
\hline Casein & - & - & - & + & + \\
\hline Gelatin & - & - & - & + & + \\
\hline Starch & + & - & + & - & + \\
\hline Xanthine & - & - & - & + & - \\
\hline Hypoxanthine & - & - & - & + & + \\
\hline \multicolumn{6}{|l|}{ Utilization of: ${ }^{*}$} \\
\hline L-Arabinose & - & + & - & + & - \\
\hline Cellobiose & + & + & + & - & + \\
\hline D-Fructose & - & + & + & + & + \\
\hline D-Mannose & + & + & + & - & - \\
\hline Sucrose & + & + & + & + & - \\
\hline D-Xylose & - & - & + & + & - \\
\hline Acetate & + & + & - & + & + \\
\hline Salicin & - & + & + & - & + \\
\hline \multicolumn{6}{|c|}{ Acid production from:* } \\
\hline L-Arabinose & - & - & - & + & - \\
\hline Cellobiose & + & + & + & - & + \\
\hline D-Galactose & + & + & - & + & + \\
\hline D-Glucose & + & + & - & + & + \\
\hline myo-Inositol & + & + & + & - & + \\
\hline Lactose & + & + & - & + & - \\
\hline Maltose & + & + & - & + & + \\
\hline D-Mannitol & + & + & - & + & + \\
\hline D-Mannose & + & + & - & - & - \\
\hline Melibiose & + & + & - & - & - \\
\hline Raffinose & + & - & - & - & - \\
\hline L-Rhamnose & - & + & - & - & + \\
\hline Sucrose & + & + & + & + & - \\
\hline Trehalose & + & + & - & + & + \\
\hline
\end{tabular}

Table 1. cont.

\begin{tabular}{|c|c|c|c|c|c|}
\hline Characteristic & 1 & 2 & 3 & 4 & 5 \\
\hline D-Xylose & - & - & + & + & - \\
\hline \multicolumn{6}{|l|}{ Enzyme activity (API ZYM)* } \\
\hline Lipase (C14) & + & - & - & + & - \\
\hline Leucine arylamidase & - & - & + & + & - \\
\hline Cystine arylamidase & - & - & + & - & - \\
\hline Acid phosphatase & - & - & + & + & - \\
\hline $\begin{array}{l}\text { Naphthol-AS-BI- } \\
\text { phosphohydrolase }\end{array}$ & - & - & + & + & - \\
\hline$N$-Acetyl- $\beta$-glucosaminidase & - & + & - & - & - \\
\hline \multicolumn{6}{|l|}{ Susceptibility to:* } \\
\hline Ampicillin & - & - & + & - & - \\
\hline Carbenicillin & + & + & + & - & + \\
\hline Cephalothin & - & - & + & - & - \\
\hline Kanamycin & $\mathrm{w}$ & + & + & - & + \\
\hline Lincomycin & + & - & + & - & - \\
\hline Novobiocin & + & - & + & - & - \\
\hline Penicillin G & - & - & + & - & - \\
\hline Polymyxin B & + & + & + & - & + \\
\hline Tetracycline & $\mathrm{w}$ & $\mathrm{w}$ & - & $\mathrm{w}$ & w \\
\hline DNA G $+C$ content $(\mathrm{mol} \%)$ & 50.6 & $47.6-47.9$ & 48.3 & 49.8 & 44 \\
\hline
\end{tabular}

${ }^{\star}$ Data were taken from this study.

from an exponentially growing culture. For this purpose, the cells were negatively stained with $1 \%(\mathrm{w} / \mathrm{v})$ phosphotungstic acid and the grids were examined after being airdried. The Gram reaction was determined by using the bioMérieux Gram stain kit according to the manufacturer's instructions. Growth at 4, 10,20, 25, 28, 30, 35, 37, 40 and $45{ }^{\circ} \mathrm{C}$ was measured on MA. Growth with $0,0.5,1.0,2.0$ and $3.0 \%(\mathrm{w} / \mathrm{v}) \mathrm{NaCl}$ was investigated in trypticase soy broth prepared according to the formula of the Difco medium except that $\mathrm{NaCl}$ was omitted and $0.45 \%(\mathrm{w} / \mathrm{v})$ $\mathrm{MgCl}_{2} .6 \mathrm{H}_{2} \mathrm{O}$ or $0.06 \%$ (w/v) $\mathrm{KCl}$ was added. Growth with $2.0-10.0 \%(\mathrm{w} / \mathrm{v}) \mathrm{NaCl}$ (in increments of $1.0 \%)$ was investigated in marine broth 2216 (MB; Difco). Growth at $\mathrm{pH} 4.5-9.5$ (in increments of $0.5 \mathrm{pH}$ units) was investigated in $\mathrm{MB}$ with the $\mathrm{pH}$ adjusted after autoclaving with $\mathrm{HCl}$ and $\mathrm{Na}_{2} \mathrm{CO}_{3}$. Growth under anaerobic conditions was determined after incubation in a Forma anaerobic chamber on MA and on MA supplemented with potassium nitrate $(0.1 \%, w / v)$, both of which had been prepared anaerobically under a nitrogen atmosphere. Catalase and oxidase activities were determined as described by Cowan \& Steel (1965). Lipolytic activity was determined by the formation of a halo on MA supplemented with tricaprylin (TCN), which was prepared as follows: a TCN emulsion (50 ml) was made by emulsifying $5 \mathrm{ml} \mathrm{TCN}$ in $45 \mathrm{ml}$ gum arabic solution $\left(200 \mathrm{mM} \mathrm{NaCl}, 10 \mathrm{mM} \mathrm{CaCl}_{2}\right.$ and $5 \%$, $\mathrm{w} / \mathrm{v}$, gum arabic) for 2 min using a Waring blender and mixed with $450 \mathrm{ml}$ MA. Nitrate reduction and hydrolysis of aesculin, gelatin, urea and Tweens 20, 40, 60 and 80 were investigated as described by Lányí (1987) with the 
modification that artificial seawater $\left(\mathrm{l}^{-1}\right.$ distilled water: $23.6 \mathrm{~g}$ $\mathrm{NaCl}, 0.64 \mathrm{~g} \mathrm{KCl}, 4.53 \mathrm{~g} \mathrm{MgCl}_{2} .6 \mathrm{H}_{2} \mathrm{O}, 5.94 \mathrm{~g} \mathrm{MgSO}_{4} \cdot 7 \mathrm{H}_{2} \mathrm{O}$ and $1.3 \mathrm{~g} \mathrm{CaCl}_{2} \cdot 2 \mathrm{H}_{2} \mathrm{O}$; Bruns et al., 2001) was used for preparation of media. Hydrolysis of casein, starch, hypoxanthine, tyrosine and xanthine was tested on MA, using the substrate concentrations described by Cowan \& Steel (1965). $\mathrm{H}_{2} \mathrm{~S}$ production was tested as described by Bruns et al. (2001). Acid production from carbohydrates was determined as described by Leifson (1963). Utilization of substrates as sole carbon and energy sources was tested as described by Baumann \& Baumann (1981) using supplementation with $2 \%(\mathrm{v} / \mathrm{v})$ Hutner's mineral base (Cohen-Bazire et al., 1957) and $1 \%(\mathrm{v} / \mathrm{v})$ vitamin solution (Staley, 1968). Susceptibility to antibiotics was tested on MA plates using antibiotic discs containing ( $\mu \mathrm{g}$, unless otherwise indicated) ampicillin (10), carbenicillin (100), cephalothin (30), chloramphenicol (100), gentamicin (30), kanamycin (30), lincomycin (15), neomycin (30), novobiocin (5), oleandomycin (15), penicillin $\mathrm{G}(20 \mathrm{U})$, polymyxin $B(100 \mathrm{U})$, streptomycin (50) and tetracycline (30). Other physiological and biochemical tests were performed with the API 20E and API ZYM systems (bioMérieux).

Cell mass of strain Gung $47^{\mathrm{T}}$ and P. rosenbergii LMG $22223^{\mathrm{T}}$ for DNA extraction and isoprenoid quinone analysis and cell mass of $P$. halotolerans LMG $22194^{\mathrm{T}}$ for isoprenoid quinone analysis were obtained from cultures grown for 3 days in $\mathrm{MB}$ at $30^{\circ} \mathrm{C}$. Chromosomal DNA was isolated and purified according to the method described previously (Yoon et al., 1996), with the exception that RNase T1 was used in combination with RNase A to minimize contamination with RNA. The 16S rRNA gene was amplified by PCR using two universal primers as described previously (Yoon et al., 1998). Sequencing and phylogenetic analysis were performed as described by Yoon et al. (2003). The identification of phylogenetic neighbours was achieved using the EzTaxon server (http://www.eztaxon.org/; Chun et al., 2007). Isoprenoid quinones were extracted according to the method of Komagata \& Suzuki (1987) and analysed using reversed-phase HPLC and a YMC ODS-A $(250 \times 4.6 \mathrm{~mm})$ column. For fatty acid methyl ester analysis, cell mass of strain Gung $47^{\mathrm{T}}, P$. rosenbergii LMG $22223^{\mathrm{T}}$, P. halotolerans
LMG $22194^{\mathrm{T}}$ and $P$. ganghwense $\mathrm{KCTC} 12328^{\mathrm{T}}$ was harvested from MA plates after incubation for 3 days at $30{ }^{\circ} \mathrm{C}$. The fatty acid methyl esters were extracted and prepared according to the standard protocol of the MIDI/ Hewlett Packard Microbial Identification System (Sasser, 1990). The DNA G+C content was determined by the method of Tamaoka \& Komagata (1984) with the modification that DNA was hydrolysed and the resultant nucleotides were analysed by reversed-phase HPLC. DNADNA hybridization was performed fluorometrically by the method of Ezaki et al. (1989) using photobiotin-labelled DNA probes and microdilution wells. Hybridization was performed with five replications for each sample. The highest and lowest values obtained in each sample were excluded and the means of the remaining three values are quoted as DNA-DNA relatedness values.

Morphological, cultural, physiological and biochemical characteristics of strain Gung $47^{\mathrm{T}}$ are given in the species description and Table 1. The almost-complete 16S rRNA gene sequence of strain Gung $47^{\mathrm{T}}$, comprising $1474 \mathrm{nt}$ (approx. 96\% of the Escherichia coli 16S rRNA gene sequence), was determined in this study. In the neighbourjoining phylogenetic tree based on 16S rRNA gene sequences, strain Gung $47^{\mathrm{T}}$ fell within the clade comprising Photobacterium species and formed a cluster with $P$. rosenbergii LMG $22223^{\mathrm{T}}, P$. lutimaris $\mathrm{DF}-42^{\mathrm{T}}, P$. halotolerans MACL $01^{\mathrm{T}}$ and $P$. ganghwense FR $1311^{\mathrm{T}}$ (Fig. 1). This cluster was also observed in phylogenetic trees constructed using the maximum-likelihood and maximum-parsimony algorithms (not shown). Strain Gung $47^{\mathrm{T}}$ exhibited 16S rRNA gene sequence similarity of 98.1, 96.3, 96.2 and $95.8 \%$ with $P$. rosenbergii LMG $22223^{\mathrm{T}}$, P. lutimaris DF$42^{\mathrm{T}}, P$. halotolerans MACL $01^{\mathrm{T}}$ and $P$. ganghwense FR $1311^{\mathrm{T}}$, respectively, and $94.3-95.5 \%$ with other type strains of species of the genus Photobacterium.

The predominant isoprenoid quinone detected in strain Gung $47^{\mathrm{T}}$ was ubiquinone-8 (Q-8), which has been found in only some members of the genus Photobacterium (Park et al., 2006; Nogi et al., 1998; Jung et al., 2007). In this study,

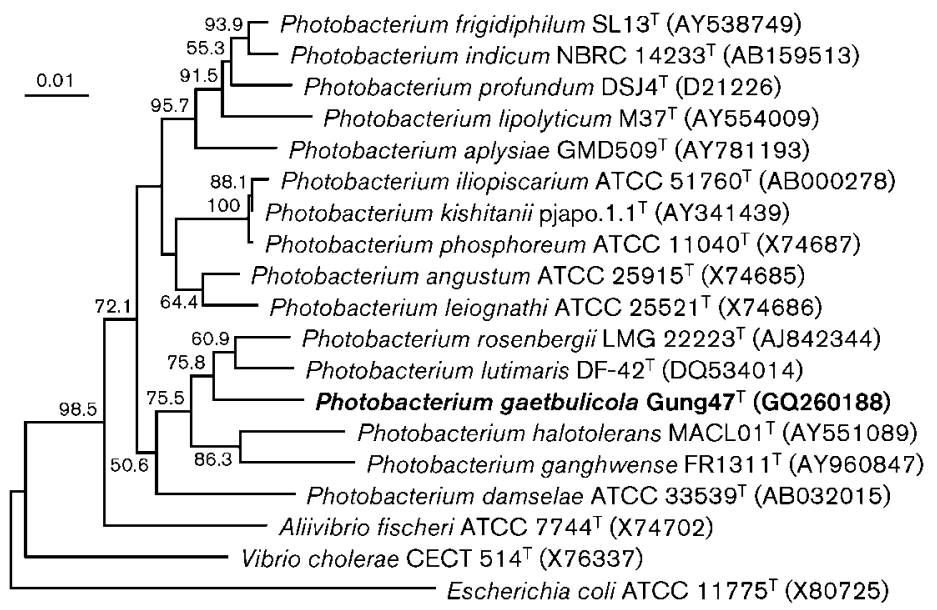

Fig. 1. Neighbour-joining phylogenetic tree based on 16S rRNA gene sequences showing the positions of strain Gung $47^{\top}$ and type strains of species of the genus Photobacterium and some other related taxa. Bootstrap values $(>50 \%)$ based on 1000 replications are shown at branch nodes. Escherichia coli ATCC $11775^{\top}$ was used as an outgroup. Bar, 0.01 substitutions per nucleotide position. 
P. rosenbergii LMG $22223^{\mathrm{T}}$ and P. halotolerans LMG $22194^{\mathrm{T}}$ were also found to have Q-8 as the predominant isoprenoid quinone (Table 1). The cellular fatty acid profile of strain Gung $47^{\mathrm{T}}$ is shown in Table 2, together with those of $P$. rosenbergii LMG $22223^{\mathrm{T}}$, $P$. halotolerans LMG $22194^{\mathrm{T}}$ and $P$. ganghwense KCTC $12328^{\mathrm{T}}$ analysed in this study and that of P. lutimaris $\mathrm{DF}-42^{\mathrm{T}}$ taken from Jung et al. (2007). The fatty acid profiles of the five strains were essentially similar in that $\mathrm{C}_{16: 1} \omega 7 c$ and/or iso- $\mathrm{C}_{15: 0} 2-\mathrm{OH}, \mathrm{C}_{16: 0}$ and $\mathrm{C}_{18: 1} \omega 7 c$ were the major fatty acids, although there were differences in the proportions of some fatty acids. The DNA G $+\mathrm{C}$ content of strain Gung $47^{\mathrm{T}}$ was $50.6 \mathrm{~mol} \%$. The results from the chemotaxonomic analyses were in agreement with the result of the phylogenetic analysis, that strain Gung $47^{\mathrm{T}}$ is a member of the genus Photobacterium (Park et al., 2006; Nogi et al., 1998; Jung et al., 2007; Tables 1 and 2).

The mean DNA-DNA relatedness between strain Gung $47^{\mathrm{T}}$ and $P$. rosenbergii LMG $22223^{\mathrm{T}}$ was $47 \%$, which indicated that the two strains are members of different genomic species (Wayne et al., 1987). Strain Gung $47^{\mathrm{T}}$ was distinguishable from its closest phylogenetic neighbours by differences in several phenotypic characteristics, most of which were determined using the same methods in this study and Jung et al. (2007). The phylogenetic distinctiveness of strain Gung $47^{\mathrm{T}}$, together with the genetic distinctiveness and differential phenotypic properties, are sufficient to show that this strain is separate from recognized Photobacterium species (Stackebrandt \& Goebel, 1994). Therefore, strain Gung $47^{\mathrm{T}}$ is considered to represent a novel species of the genus Photobacterium, for which the name Photobacterium gaetbulicola sp. nov. is proposed.

\section{Description of Photobacterium gaetbulicola sp. nov.}

Photobacterium gaetbulicola [gaet.bu.li.co'la. N.L. n. gaetbulum - $i$ gaetbul, the Korean name for a tidal flat; L. suff. cola (from L. n. incola) a dweller, inhabitant; N.L. fem. n. gaetbulicola a dweller of a tidal flat].

Cells are Gram-negative, motile, non-spore-forming and rod- or oval-shaped $(0.4-1.0 \times 1.0-5.0 \mu \mathrm{m})$. After incubation on $\mathrm{MA}$ at $30{ }^{\circ} \mathrm{C}$ for 3 days, colonies are circular to irregular, flat, smooth, glistening, greyish-yellow and 4.0$6.0 \mathrm{~mm}$ in diameter. Growth occurs at 10 and $40{ }^{\circ} \mathrm{C}$ (optimum $30{ }^{\circ} \mathrm{C}$ ), but not at 4 or $45^{\circ} \mathrm{C}$. Growth occurs at $\mathrm{pH} 5.0$ (optimum $\mathrm{pH}$ 7.0-8.0), but not at $\mathrm{pH}$ 4.5. Growth occurs with $0-8.0 \%$ (w/v) $\mathrm{NaCl}$ (optimum 2.0-5.0\%); growth occurs without $\mathrm{NaCl}$ if $\mathrm{Mg}^{2+}$ ions are added. Growth occurs under anaerobic conditions on MA and on MA supplemented with nitrate. Catalase- and oxidasepositive. Nitrate reduction is positive. Arginine dihydrolase, lysine decarboxylase, ornithine decarboxylase and tryptophan deaminase are absent. The predominant ubiquinone is Q-8. The major fatty acids ( $>10 \%$ of total fatty acids) are $\mathrm{C}_{16: 1} \omega 7 c$ and/or iso- $\mathrm{C}_{15: 0} 2-\mathrm{OH}, \mathrm{C}_{16: 0}$ and $\mathrm{C}_{18: 1} \omega 7 c$. Other phenotypic properties are shown in Table 1 . The DNA G $+\mathrm{C}$ content of the type strain is $50.6 \mathrm{~mol} \%$ (HPLC).
Table 2. Cellular fatty acid compositions of strain Gung $47^{\top}$ and its closest phylogenetic neighbours

Strains: 1, P. gaetbulicola sp. nov. Gung $47^{\mathrm{T}} ; 2$, P. rosenbergii $\mathrm{LMG}$ $22223^{\mathrm{T}}$; 3, P. lutimaris DF-42 ${ }^{\mathrm{T}} ; 4$, P. halotolerans LMG $22194^{\mathrm{T}} ; 5, P$. ganghwense KCTC $12328^{\mathrm{T}}$ (data from Jung et al., 2007). Data were taken from this study unless indicated. Values are percentages of total fatty acids; fatty acids that represented $<1.0 \%$ in all strains were omitted.

\begin{tabular}{|c|c|c|c|c|c|}
\hline Fatty acid & 1 & 2 & 3 & 4 & 5 \\
\hline \multicolumn{6}{|l|}{ Straight-chain } \\
\hline$C_{12: 0}$ & 1.7 & 2.1 & 2.4 & 6.3 & 3.1 \\
\hline $\mathrm{C}_{14: 0}$ & 4.2 & 3.5 & 2.4 & 1.1 & 4.0 \\
\hline $\mathrm{C}_{15: 0}$ & 2.9 & 3.3 & 2.1 & 0.8 & 0.8 \\
\hline $\mathrm{C}_{16: 0}$ & 14.0 & 15.5 & 13.1 & 21.5 & 22.3 \\
\hline $\mathrm{C}_{16: 0} \mathrm{~N}$ alcohol & 0.5 & 0.3 & - & - & 1.3 \\
\hline $\mathrm{C}_{17: 0}$ & 1.0 & 1.9 & - & 1.5 & 1.0 \\
\hline \multicolumn{6}{|l|}{ Branched } \\
\hline iso- $\mathrm{C}_{15: 0}$ & 6.9 & 3.9 & 5.0 & 0.1 & 0.5 \\
\hline iso- $\mathrm{C}_{16: 0}$ & 0.4 & 1.9 & - & 2.1 & 0.4 \\
\hline iso- $\mathrm{C}_{17: 0}$ & 3.5 & 5.1 & 1.8 & 0.4 & 1.0 \\
\hline iso- $\mathrm{C}_{17: 1} \omega 9 c$ & 1.4 & 1.8 & 1.8 & - & - \\
\hline \multicolumn{6}{|l|}{ Unsaturated } \\
\hline $\mathrm{C}_{16: 1} \omega 9 c$ & - & - & - & 1.5 & - \\
\hline $\mathrm{C}_{17: 1} \omega 8 c$ & 0.6 & 1.1 & - & 1.6 & 0.5 \\
\hline $\mathrm{C}_{18: 1} \omega 6 c$ & 3.1 & - & - & 3.4 & - \\
\hline $\mathrm{C}_{18: 1} \omega 7 c$ & 10.3 & 11.9 & 13.0 & 16.3 & 21.3 \\
\hline $\mathrm{C}_{16: 1} \omega 7 c$ alcohol & 0.7 & 0.6 & 1.2 & - & 2.1 \\
\hline \multicolumn{6}{|l|}{ Hydroxy } \\
\hline $\mathrm{C}_{11: 0} 2-\mathrm{OH}$ & 2.8 & - & - & - & - \\
\hline $\mathrm{C}_{12: 0} 3-\mathrm{OH}$ & 2.8 & 2.3 & 2.6 & 6.2 & 2.6 \\
\hline \multicolumn{6}{|l|}{ Summed features ${ }^{*}$} \\
\hline 2 & 3.7 & 3.4 & 3.0 & 6.0 & 3.9 \\
\hline 3 & 33.6 & 35.6 & 43.3 & 24.5 & 31.0 \\
\hline
\end{tabular}

${ }^{\star}$ Summed features represent two or three fatty acids that cannot be separated by the Microbial Identification System. Summed feature 2 consisted of iso- $\mathrm{C}_{16: 1}$ and/or $\mathrm{C}_{14: 0} 3-\mathrm{OH}$. Summed feature 3 consisted of $\mathrm{C}_{16: 1} \omega 7 c$ and/or iso- $\mathrm{C}_{15: 0} 2-\mathrm{OH}$.

The type strain, Gung $47^{\mathrm{T}}\left(=\mathrm{KCTC} 22804^{\mathrm{T}}=\mathrm{CCUG}\right.$ $58399^{\mathrm{T}}$ ), was isolated from a tidal flat of Gung harbour on the west coast of Korea.

\section{Acknowledgements}

This work was supported by grants from the National Fisheries Research and Development Institute (NFRDI) and the 21C Frontier Program of Microbial Genomics and Applications (grant no. MG050401-2-0) from the Ministry of Education, Science and Technology (MEST) of the Republic of Korea.

\section{References}

Anzai, Y., Kim, H., Park, J.-Y., Wakabayashi, H. \& Oyaizu, H. (2000). Phylogenetic affiliation of the pseudomonads based on 16S rRNA sequence. Int J Syst Evol Microbiol 50, 1563-1589. 
Ast, J. C., Cleenwerck, I., Engelbeen, K., Urbanczyk, H., Thompson, F. L., De Vos, P. \& Dunlap, P. V. (2007). Photobacterium kishitanii sp. nov., a luminous marine bacterium symbiotic with deep-sea fishes. Int J Syst Evol Microbiol 57, 2073-2078.

Baumann, P. \& Baumann, L. (1981). The marine Gram-negative eubacteria: genera Photobacterium, Beneckea, Alteromonas, Pseudomonas, and Alcaligenes. In The Prokaryotes, pp. 1302-1331. Edited by M. P. Starr, H. Stolp, H. G. Trüper, A. Balows \& H. G. Schlegel. Berlin: Springer.

Beijerinck, M. W. (1889). Le Photobacterium luminosum, bactérie lumineuse de la Mer du Nord. Arch Neerl Sci Exactes Nat 23, 401-427 (in French).

Boisvert, H., Chatelain, R. \& Bassot, J.-M. (1967). Etude d'un Photobacterium isolé de l'organe lumineux de poissons Leiognathidae. Ann Inst Pasteur (Paris) 112, 520-524 (in French).

Bruns, A., Rohde, M. \& Berthe-Corti, L. (2001). Muricauda ruestringensis gen. nov., sp. nov., a facultatively anaerobic, appendaged bacterium from German North Sea intertidal sediment. Int Syst Evol Microbiol 51, 1997-2006.

Chun, J., Lee, J.-H., Jung, Y., Kim, M., Kim, S., Kim, B. K. \& Lim, Y.-W. (2007). EzTaxon: a web-based tool for the identification of prokaryotes based on $16 \mathrm{~S}$ ribosomal RNA gene sequences. Int J Syst Evol Microbiol 57, 2259-2261.

Cohen-Bazire, G., Sistrom, W. R. \& Stanier, R. Y. (1957). Kinetic studies of pigment synthesis by nonsulfur purple bacteria. J Cell Comp Physiol 49, 25-68.

Cowan, S. T. \& Steel, K. J. (1965). Manual for the Identification of Medical Bacteria. London: Cambridge University Press.

Ezaki, T., Hashimoto, Y. \& Yabuuchi, E. (1989). Fluorometric deoxyribonucleic acid-deoxyribonucleic acid hybridization in microdilution wells as an alternative to membrane filter hybridization in which radioisotopes are used to determine genetic relatedness among bacterial strains. Int J Syst Bacteriol 39, 224-229.

Farmer, J., III \& Hickman-Brenner, F. (2006). The genera Vibrio and Photobacterium. In The Prokaryotes, 3rd edn, vol. 6, pp. 508-563. Edited by M. Dworkin, S. Falkow, E. Rosenberg, K. H. Schleifer \& E. Stackebrandt. New York: Springer.

Jung, S.-Y., Jung, Y.-T., Oh, T.-K. \& Yoon, J.-H. (2007). Photobacterium lutimaris sp. nov., isolated from a tidal flat sediment in Korea. Int $J$ Syst Evol Microbiol 57, 332-336.

Komagata, K. \& Suzuki, K. (1987). Lipid and cell-wall analysis in bacterial systematics. Methods Microbiol 19, 161-207.

Lányí, B. (1987). Classical and rapid identification methods for medically important bacteria. Methods Microbiol 19, 1-67.

Leifson, E. (1963). Determination of carbohydrate metabolism of marine bacteria. J Bacteriol 85, 1183-1184.

Nogi, Y., Masui, N. \& Kato, C. (1998). Photobacterium profundum sp. nov., a new, moderately barophilic bacterial species isolated from a deep-sea sediment. Extremophiles 2, 1-7.

Onarheim, A. M., Wiik, R., Burghardt, J. \& Stackebrandt, E. (1994). Characterization and identification of two Vibrio species indigenous to the intestine of fish in cold sea water; description of Vibrio iliopiscarius sp. nov. Syst Appl Microbiol 17, 370-379.

Park, Y. D., Baik, K. S., Seong, C. N., Bae, K. S., Kim, S. \& Chun, J. (2006). Photobacterium ganghwense sp. nov., a halophilic bacterium isolated from sea water. Int J Syst Evol Microbiol 56, 745-749.

Reichelt, J. L. \& Baumann, P. (1973). Taxonomy of the marine, luminous bacteria. Arch Mikrobiol 94, 283-330.
Reichelt, J. L., Baumann, P. \& Baumann, L. (1976). Study of genetic relationships among marine species of the genera Beneckea and Photobacterium. Arch Microbiol 110, 101-120.

Rivas, R., Garcia-Fraile, P., Mateos, P. F., Martínez-Molina, E. \& Velázquez, E. (2006). Photobacterium halotolerans sp. nov., isolated from Lake Martel in Spain. Int J Syst Evol Microbiol 56, 1067-1071.

Sasser, M. (1990). Identification of bacteria by gas chromatography of cellular fatty acids, MIDI Technical Note 101. Newark, DE: MIDI Inc.

Seo, H. J., Bae, S. S., Lee, J. H. \& Kim, S. J. (2005a). Photobacterium frigidiphilum sp. nov., a psychrophilic, lipolytic bacterium isolated from deep-sea sediments of Edison Seamount. Int J Syst Evol Microbiol 55, 1661-1666.

Seo, H. J., Bae, S. S., Yang, S. H., Lee, J. H. \& Kim, S. J. (2005b). Photobacterium aplysiae sp. nov., a lipolytic marine bacterium isolated from eggs of the sea hare Aplysia kurodai. Int J Syst Evol Microbiol 55, 2293-2296.

Smith, S. K., Sutton, D. C., Fuerst, J. A. \& Reichelt, J. L. (1991). Evaluation of the genus Listonella and reassignment of Listonella damsela (Love et al.) MacDonell and Colwell to the genus Photobacterium as Photobacterium damsela comb. nov. with an emended description. Int J Syst Bacteriol 41, 529-534.

Stackebrandt, E. \& Goebel, B. M. (1994). Taxonomic note: a place for DNA-DNA reassociation and $16 \mathrm{~S}$ rRNA sequence analysis in the present species definition in bacteriology. Int J Syst Bacteriol 44, 846-849.

Staley, J. T. (1968). Prosthecomicrobium and Ancalomicrobium: new prosthecate freshwater bacteria. J Bacteriol 95, 1921-1942.

Tamaoka, J. \& Komagata, K. (1984). Determination of DNA base composition by reversed-phase high-performance liquid chromatography. FEMS Microbiol Lett 25, 125-128.

Thompson, F. L., Thompson, C. C., Naser, S., Hoste, B., Vandemeulebroecke, K., Munn, C., Bourne, D. \& Swings, J. (2005). Photobacterium rosenbergii sp. nov. and Enterovibrio coralii sp. nov., vibrios associated with coral bleaching. Int J Syst Evol Microbiol 55, 913-917.

Urakawa, H., Kita-Tsukamoto, K. \& Ohwada, K. (1999). Reassessment of the taxonomic position of Vibrio iliopiscarius (Onarheim et al. 1994) and proposal for Photobacterium iliopiscarium comb. nov. Int J Syst Bacteriol 49, 257-260.

Wayne, L. G., Brenner, D. J., Colwell, R. R., Grimont, P. A. D., Kandler, O., Krichevsky, M. I., Moore, L. H., Moore, W. E. C., Murray, R. G. E. \& other authors (1987). International Committee on Systematic Bacteriology. Report of the ad hoc committee on reconciliation of approaches to bacterial systematics. Int J Syst Bacteriol 37, 463-464.

Xie, C.-H. \& Yokota, A. (2004). Transfer of Hyphomicrobium indicum to the genus Photobacterium as Photobacterium indicum comb. nov. Int J Syst Evol Microbiol 54, 2113-2116.

Yoon, J.-H., Kim, H., Kim, S.-B., Kim, H.-J., Kim, W. Y., Lee, S. T., Goodfellow, M. \& Park, Y.-H. (1996). Identification of Saccharomonospora strains by the use of genomic DNA fragments and rRNA gene probes. Int $J$ Syst Bacteriol 46, 502-505.

Yoon, J.-H., Lee, S. T. \& Park, Y.-H. (1998). Inter- and intraspecific phylogenetic analysis of the genus Nocardioides and related taxa based on 16S rRNA gene sequences. Int J Syst Bacteriol 48, 187-194.

Yoon, J.-H., Kim, I.-G., Shin, D.-Y., Kang, K. H. \& Park, Y.-H. (2003). Microbulbifer salipaludis sp. nov., a moderate halophile isolated from a Korean salt marsh. Int J Syst Evol Microbiol 53, 53-57.

Yoon, J. H., Lee, J. K., Kim, Y. O. \& Oh, T. K. (2005). Photobacterium lipolyticum sp. nov., a bacterium with lipolytic activity isolated from the Yellow Sea in Korea. Int J Syst Evol Microbiol 55, 335-339. 